\title{
Staatliche Dreisffeffiegung
}

Gín Beitrag zur Friégg̈:Dreigpolitíf

\author{
Bon
}

\section{Furt Biedenfeld}

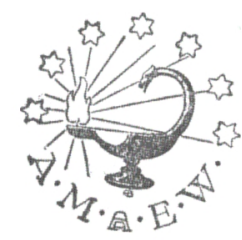

1918

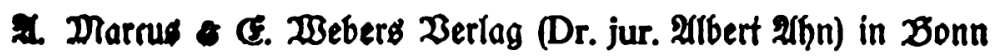

G.C. 


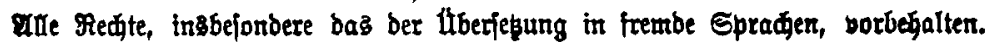
Copyright by A. Marcus \& E. Webers Verlag, Bonn 1918. 